\title{
Zakat Regulation as a Reduction of Income Tax in Indonesia
}

\section{Aripin Marpaung}

Faculty of Sharia and Law, Universitas Islam Negeri Sumatera Utara, Indonesia arifinmarpaung@uinsu.ic.id

\begin{abstract}
Zakat is one part of the rules of social security in Islam, in a deeper and broader scope, which includes aspects of material and spiritual life. Zakat is also a financial, economic, social, political, moral and religious system at the same time. Zakat as a financial and economic system, because it is a specified property tax. Zakat is a financial source of baitul mall in Islam that is continuous. Zakat as a social system, because it functions to save people from various weaknesses, overcome various disasters and accidents, provide humanitarian assistance, who are helping those who do not have, the strong help the weak. Zakat and tax are the material obligations of a citizen of his country and are a source of state income used to finance state expenses and needs. the position of zakat cannot be replaced by taxation. the problem in Indonesia where the majority of the population is Muslim, in addition to being obligatory zakat they are also burdened with various taxes, so that a middle way can be taken,namely reducing the amount of tax by the amount of zakat that has been paid. Thus a taxpayer can still pay obligations as citizens and continue to fulfill their religious obligations.
\end{abstract}

Keywords regulation; tax deduction for alms, income

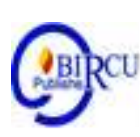

\section{Introduction}

The obligation of all Muslims to be carried out as obedient servants of Allah is to issue part of the treasures to be tithed as an expression of gratitude to Allah who has always given endless gifts, mercy and abundance of wealth. The obligation of zakat has been taught by the Prophet Muhammad. However, at the time of the Prophet Muhammad (peace and blessings be upon him) and khulafa 'ar-Rashidin (Abu Bakr, Umar, Usman and Ali ra.) The obligation of zakat was only imposed specifically on Muslims, while non-Muslim residents were not ordered to pay zakat but were obliged to pay taxes. Thus no population is subject to a double burden (zakat and tax).

Zakat and tax, although both are obligations in the field of assets, both have a special philosophy and both have different characteristics and principles, different sources, targets, parts and levels, as well as different principles, objectives and guarantees, but there are also sides the similarity. Zakat and tax are two things that can be reviewed from semantic aspects and the purpose of having differences. Tax is a requirement that has been established by the state as a civic duty. Tax payments of various types and types are purely worldly matters that are not related to the spiritual dimension and are carried out by citizens (Muslim and nonMuslim).

Zakat as an obligation for Muslims if carried out properly will have a very concrete impact on the process of community economic growth. Zakat, besides functioning as a means of getting closer to God, also functions as a means of creating harmony between the rich and poor. In addition, issuing zakat can prevent the monopoly of wealth by wealthy people. Aside from being an obligation of Muslims, zakat is a religious institution in an effort to realize 
social justice for all Muslims. Therefore, if managed properly and properly, then zakat can be used as one of the sources of the economic potential of the people which can be utilized for the welfare of Muslims in Indonesia, especially to overcome poverty and eliminate social inequalities. For this purpose, there needs to be a professional and responsible management of zakat which is carried out jointly with the community and the Government.

Zakat is one part of the rules of social security in Islam, in a deeper and broader scope, which includes aspects of material and spiritual life. Zakat is also a financial, economic, social, political, moral and religious system at the same time. Zakat as a financial and economic system, because it is a specified property tax. Zakat is a financial source of baitul mall in Islam that is continuous. Zakat as a social system, because it functions to save people from various weaknesses, overcome various disasters and accidents, provide humanitarian assistance, who are helping those who do not have, the strong help the weak. Zakat also serves to eliminate the desire and envy of the weak to the rich. Zakat as a political system, because originally the state managed the collection and distribution of its goals / mustahiknya by paying attention to the principle of justice, can meet the needs and put the important things first. Zakat is also a moral system, because it aims to cleanse the souls of rich people from destructive stinginess and selfishness that hates others. In the beginning, zakat was a religious system, because it was one of the pillars of faith and included the highest worship that draws closer to Allah SWT.

Regarding zakat as a deduction from tax payments (in this case income tax), it has been set since Law No. 38 of 1999 concerning zakat management, then confirmed by the latest zakat law in Law no. 23 of 2011 concerning zakat management. The background of this reduction is explained in the explanation of article 14 paragraph (3) of Law no. 38 of 1999 that the deduction of zakat from profit or taxable residual income is to pay zakat and tax. The background of this reduction is explained in the explanation of article 14 paragraph (3) of Law no. 38 of 1999 that deduction of zakat from profit or taxable residual income is paying zakat and taxes.

\section{Review of Literatures}

\subsection{Theory of Zakat}

Zakat is the basic word of zaka which means holy, blessing, growing, and praiseworthy, all of which are very popular in the translation of the Koran and the Hadith. Something is said zaka when he grows and develops, and someone is called zaka when he is good and commendable. The definition of zakat according to the term is to issue some (certain) assets that Allah SWT has obliged to give to those who are entitled to receive them, with certain levels, haul and fulfill their requirements and harmony. Zakat is ijtima'iyyah maaliyyah worship which has a very important, strategic and decisive position, both in terms of the teachings of Islam and the development of the welfare of the people.

The meaning of zakat itself is the hope of blessing, the purity of the soul, and therein is goodness as the word of Allah SWT in surah At-Tawbah 103:

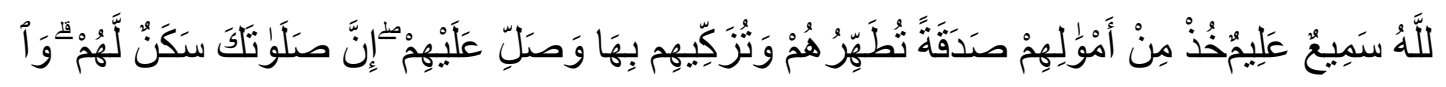

Reference: https://tafsirweb.com/3119-quran-surat-at-taubah-ayat-103.html 
It means: "Take alms from a portion of their property, with that alms you cleanse and purify them and pray for them. Verily, your prayers (become) peace of mind for them and Allah heareth again knows.

In terms of fiqh terminology that was put forward by Taqiyuddin Abu Bakr, zakat means a number of assets given to people who are entitled to certain conditions. Whereas according to the law of zakat is a property that must be issued by a Muslim or business entity to be given to those entitled to receive it in accordance with Islamic law.

The definition of zakat according to shar'i in the view of fiqh experts has various limits. Among fiqh expert opinions as follows:

a. Al-Syirbini, namely zakat as a name for certain levels of certain assets that must be utilized for certain groups of society.

b. brahim 'Usman asy-Sya'lan, zakat is giving property rights to the needy people who are Muslims, not Hashim descendants and not slaves who have been freed by Hashim descendants, provided the release of the benefits of the property given is from the beginner, from all aspects because Allah.

Zakat is a worship that has multiple values, hablum minallah (vertical) and hablum minannas (horizontal), ritual and social dimensions. That is, people who always pay zakat will increase the faith of Allah SWT and foster a sense of social care, and build social relations.

\subsection{Theory of Tax}

Tax is a public contribution to the State treasury (transfer of private sector wealth to the law) based on the Act (can be forced) with no reciprocal services (tegen prestatie) which can be directly demonstrated and used to finance public expenditure (publieke uitgaven).

Tax is a compulsory levy paid by the people to the state and will be used for the benefit of the government and the general public. People who pay taxes will not feel the benefits of taxes directly, because the tax is used for public purposes, not for personal gain. Taxes are one source of government funds for development, both the central and regional governments. Tax collection can be forced because it is carried out according to the law. (Siregar, 2019)

Contemporary economists define tax as an obligation to pay cash determined by the government or a competent authority in the absence of certain rewards. These government provisions are in accordance with the ability of the owner of the property and are allocated to meet general food needs and to meet the demands of financial politics for the government.

In Islamic law there are several terms that can be interpreted as taxes. For example: The term jizyah is a part of wealth taken from unbeliever's zimmi as an obligation for him because he has been protected by his personal safety and property by the Islamic government. Al-kharaj is part of a wealth that has been issued by every citizen who is subject to the rule of the Islamic government for those who have agriculture or plantations. Adh-dariibah is a part of wealth issued by unbelievers which have been carried out by the Islamic army as al-Harbi by imposing a tax of $10 \%$ of his wealth. Al- 'usyuriyah is a tax issued by every citizen under the authority of the Islamic government consisting of Muslims, Ahlul Dzimmi and Ahlul Harbi. This is said to be 'isyuriyah because $10 \%$ is excluded from the wealth of Ahlul Harbi with the term "al-" usyur "and 5\% is excluded from the wealth of Ahlul Dzimmi with the term" Nusful' Usyur "and $2.5 \%$ is excluded from the wealth of Muslim people with the term "Rubu'ul 'usyur". Taxes like this are called "Al-Kharaaf.

However, the taxation law No. 36 of 2008 formulates the definition of tax I chapter I as follows: "Income tax is imposed on individuals or individuals and entities with respect to income received or obtained for one year. 


\subsection{Regulation Zakat Tax Reduction in Indonesia}

Regarding the regulatory process for managing zakat until zakat reduces tax payments (in this case income tax), this has been regulated since Law No. 38 of 1999 concernin management of Zakat, and then further emphasized by the latest Zakat Act which replaces Law 38/1999 namely Law No. 23 of 2011 concerning Management of Zakat.

More specifically, in the opening of Law No.38 of 1999 concerning the management of zakat, the basic reasons for issuing the law are:

1. That the Republic of Indonesia guarantees the independence of each resident to worship according to their respective religions;

2. That the payment of zakat is an obligation of Indonesian Muslims who are able and the result of zakat collection is a potential source of funds to realize public welfare;

3. That zakat is a religious institution to realize social justice for all Indonesian people by taking into account the poor people.

4. Those efforts to improve the management system of zakat need to be continuously improved so that the implementation of zakat is more successful and efficient it can be accounted.

Some of the considerations above are the basis for the issuance of Law No. 38 of 1999 with this law it is hoped that the management of zakat will be more effective and efficient. This is done so that Muslims in Indonesia who have paid zakat are not subject to a double burden. In addition to paying zakat, he also has a State obligation to pay taxes. With Law No. 38 of 1999 concerning Management of zakat, efforts can reduce the multiple burdens that have been borne by Muslims in Indonesia. Therefore the guideline issued is in the form of deduction of zakat from profit / taxable residual income.

This is indeed expected by the government in accordance with the sound of article 14 paragraph 3 of the law reads: "zakat that has been paid to amil zakat bodies or amil zakat institutions can be deducted from the profit / taxable residual income of the taxpayer concerned in accordance with the regulations current regulation."

The regulations governing income tax issues specifically relating to the issue of zakat are Law No. 17 of 2000 concerning income tax can be seen from article 4 paragraph 3 letter a No.1 stated that "which is not included as a tax object is donation assistance, including zakat received by amil zakat bodies or amil zakat institutions established or authorized by the instructor and the recipients of zakat are entitled ".

Then article 9 paragraph 1 letter g states: "to determine the amount of taxable income for taxpayers in the country and the permanent establishment must not be deducted: donated assets, assistance or donations and inheritance as referred to in article 4 paragraph 3 letters a and $b$ except zakat on income that is clearly paid by individual taxpayers of Islam or domestic taxpayers owned by Muslims to amil zakat bodies or amil zakat institutions determined or authorized by the government."

The above provisions clearly state that zakat is required as an element of income deduction to determine the taxable income used as the basis for taxation. To determine taxable income an income must be reduced by costs as explained in article 6 of Law No.17 of 2000. Whereas to determine the taxable income to be multiplied by the tax rate. An income is also possible by law can be reduced by certain expenses, as stipulated in article 9 paragraph 1 letter g of Law No.17 of 2000.

\subsection{Legal Basis for Zakat Tax Reduction in Indonesia}

Since 1968, Indonesian Muslims have struggled to form institutions working in the field of zakat. This desire was answered by the birth of Law No. 38 of 1999 concerning management of zakat, although it still does not satisfy all parties, but at least with the 
existence of the law, efforts to improve the welfare of the people through zakat are starting to open. With the Law No. 38 of 1999 funds collected in the form of ZIS (zakat, infaq and sadaqoh) can be managed more effectively and efficiently through a special institution authorized by the government namely the amil zakat (BAZ) or amil zakat institution (LAZ).

As for the zakat that can be lawfully deducted from income to determine the amount of taxable income, the taxpayer must attach proof of payment of zakat on the income he has paid on the tax return. This right is in accordance with the decision of the Director General of Tax No.KEP-214 / PJ / 2001 dated March 15, 2001. The complete provisions of article 3 No.39 of the Director General of Taxes Decree No. KEP-214 / PJ / 2001 are as follows: "information or other documents that must be attached to the personal income taxpayers who carry out the bookkeeping is proof of payment of zakat on income paid by taxpayers of individuals of Islam to the amil zakat body or zakat institutions established and approved by the government. "

Regulation of the Minister of Finance No.254 / PMK.03 / 2010 Article 1 paragraph 1 also explains that zakat can be deducted as a deduction for taxable income that reads "religious donations that are obligatory for taxpayers of individuals of different religions than Islam by domestic taxpayers owned by adherents of religions other than Islam which are recognized in Indonesia which are paid to religious institutions established and authorized by the government." While the things that explain the requirements for proof of zakat deposit as a deduction for taxable income are affirmed in article 4 paragraphs 1 and 2 that read "if expenses for zakat or religious donations which are obligatory are not paid to amil zakat bodies or religious zakat institutions as referred to in Article 1 paragraph 1 then the expenditure cannot be deducted from gross income. "

The legal basis for Zakat can be a tax deduction contained in the zakat law and tax law. In Law No. 17 of 2000 concerning the Third Amendment to Law No. 7 of 1983 concerning Income Tax, which is regulated in Article 4 paragraph (3) letter a number 1 which reads:

"Not included as Tax Objects are: donation assistance, including zakat received by amil zakat bodies or amil zakat institutions established or authorized by the Government and entitled recipients of zakat."

In addition, Article 1 paragraph (1) PP No. 60 of 2010 concerning zakat or religious donations which are mandatory that can be deducted from gross income also determine:

"Zakat or obligatory religious donations which can be deducted from gross income include:

a. zakat on income paid by individual taxpayers of the Islamic religion and / or by domestic corporate taxpayers owned by Muslims to amil zakat or amil zakat institutions established or authorized by the Government; or

b. religious contributions which are mandatory for individual taxpayers of other religions than Islam and / or by domestic corporate taxpayers owned by adherents of religions other than Islam, which are recognized in Indonesia paid to religious institutions established or authorized by the Government"

In Law No.23 of 2011 concerning the management of zakat is found in Article 22 which reads:

"Zakat paid by muzaki to BAZNAS or LAZ is deducted from taxable income."

Zakat on income which is permitted as a deduction from gross income must fulfill the following:

1. Zakat as a deduction for taxable income (PKP) only applies to muzakki who have a Taxpayer Identification Number (NPWP). 
2. Zakat paid to the amil zakat body or zakat institution will get proof of payment of zakat. And proof of zakat deposit will be obtained after muzakki has a Zakat Obligatory Number (NPWZ).

3. The type of zakat that is permitted to be used as a deduction from gross income is the type of zakat on income. Zakat other than zakat on income cannot be used as a deduction from gross income.

4. Payment of zakat on income is an individual taxpayer who is a Muslim and / or a domestic corporate taxpayer owned by a Muslim. The reduction in gross income by income zakat, at the end of the year, is reported in the Annual Tax Return Income Tax Returns of the individual taxpayer and / or by the domestic taxpayer concerned.

5. Zakat on income can be in the form of money or which is equivalent to money. Payments equivalent to money are valued at the market price at the time the zakat on the income is paid.

6. If in the tax year the income reported in the Annual Notification Letter (SPT), zakat on income has not been paid, then the reduction in zakat on income can be done in the tax year the payment is made; and Taxpayers can show that gross income has been reported in the Annual Tax Return (SPT) of the previous tax year.

7. Taxpayers who reduce their gross income by alms on income must attach a photocopy of proof of payment to the Annual Tax Year Income Tax Return (SPT) to reduce gross income with alms on income. Proof of payment regulated in Regulation of the Director General of Tax Number PER - 6 / PJ / 2011 is:

a. can be in the form of proof of payment directly or through a bank account transfer, or payment through an Automatic Teller Machine (ATM), and

b. at least loading:

1) The full name of the taxpayer and the taxpayer registration number (NPWP) of the payer;

2) Amount of payment;

3) Payment date;

4) The name of the amil zakat body; amil zakat institutions; or religious institutions established or authorized by the Government; and

5) The signature of the officer of the amil zakat body; amil zakat institutions; or religious institutions, established or authorized by the Government, in proof of payment, if paid directly; or

6) Validation of bank officers on proof of payment if payment via bank account transfers.

8. The place for payment of zakat on such income is the amil zakat body or amil zakat institution established or authorized by the Government. If the expenditure for zakat on that income is not paid to the amil zakat body or amil zakat institution established or authorized by the Government, then the zakat on that income cannot be deducted from gross income.

\section{Research Method}

Normative juridical research with a statute approach with analytical descriptive research specifications that describes analytically the legal issues related to zakat management, tax reduction with tax payments through governmental institutions or amil zakat institutions. The qualitative method as a research procedure with systematic responsibility in the discussion is presented in harmony with the theme of the discussion. 


\section{Conclusion}

Zakat is part of the assets with certain conditions, which Allah SWT requires the owner, to be handed over to those entitled to receive them, with certain conditions as well. Since the second year of hijriyah, zakat and shadaqah have become the country's main income. Effective and professional management of zakat is only realized in the ninth year of Hijriyah, when Islam has been established, the Islamic territory has expanded and people have flocked to Islam. At that time the zakat regulations were arranged which included; zakat collection system, zakat limits and zakat percentage levels for different items, as well as the determination of the payroll system (rights) of zakat officers (Amil).

Zakat can reduce tax payments as stipulated in Law No. 23 of 2011 concerning Management of Zakat and article 9 paragraph (1) of the Income Tax Act. Whereas a body or institution designated as recipient of zakat or religious donations that are obligatory can be deducted from gross income is regulated in Regulation of the Director General of Tax Number PER-15 / PJ / 2012 in effect since June 11, 2012 which was previously regulated by Director General of Taxes No . PER-33 / PJ / 2011 which include BAZNAS, LAZ, LEMSAKTI, BDDN YADP and others.

The essence of zakat and tax is the same, namely for the welfare or common interest, especially the tax rate is always higher than the zakat level so that it can be said that people who have paid taxes have automatically paid zakat, while people who pay zakat do not necessarily have paid taxes.

If the tax level is generally considered reasonable (less than 20\%), the zakat must be paid in accordance with the provisions of zakat. However, if the tax is more than $20 \%$, then the taxpayers can aim at the same time to pay zakat because the contribution to welfare and common interests is quite large.

\section{References}

al-Qaradhawi, Yusuf, Al-Ibadah fil-Islam, Bairut:Muassasah Risalah, 1993. al-Syirbini, Muhammad, al-Iqna, Mesir: Musthafa al-Babi al-Halabi, 1940. ash-Shiddieq, Tengku M.Hasbi, Pedoman Zakat, Jakarta: PT.Pustaka Rizki Putra,1999. asy-Syar'lan,Ibrahim 'Usman, Nizhamu Misa fi al-Zakah wa Tauzi'u al-Ghana'im, Riyad: Tp, $1402 \mathrm{H}$.

Asy-Syaukaaniy, Nailul Author, Juz VIII, Mesir: Mustahafaa Al-baby Al-Halaby.

BAZNAS, Implementasi Zakat Sebagai Pengurang Penghasilan Kena Pajak, makalah forum zakat.

Hafidhuddin, Didin. (2005). Anda Bertanya tentang Zakat Infak \& Sedekah Kami Menjawab, Jakarta:Badan Amil Zakat Nasional (BAZNAS).

Inayah, Gazi. (2003). “Teori Komprehensip Tentang Zakat dan Pajak", Yogyakarta: Tiara Wacana Yogya.

Modul Penyuluhan Zakat. (2013). Kementrian Agama RI Direktorat Jendral BIMAS Islam Direktorat Pemberdayaan Zakat.

Najuddin. (2003). Masaail Fiqhiyyah, Jakarta: Kalam Mulya.

Peraturan Menteri Keuangan No.254/PMK.03/2010 tentang Tata Cara Pembebanan Zakatatau Sumbangan Keagamaan yang Sifatnya Wajib dapat dikurangkan dari Penghasilan.

R.Mansyuri. Pembahasan Mendalam atas Penghasilan. Jakarta: Penerbit YP4, 2000.

Siregar, R. et al. (2019). The Effect of Corporate Taxpayer Compliance, the Increase of Corporate Taxpayers' Number and Tax Audits on Income Tax Receipts of Article 25 
with Taxation Sanctions as a Moderating Variable in KPP Pratama Medan Petisah. Budapest International Research and Critics Institute-Journal (BIRCI-Journal). P. 385400

Soemitro. (1992). Rahmat, Dasar-dasar Hukum Pajak dan Pajak Pendapatan, Yogyakarta: Libert.

Taqiyudin Abu Bakr ibn Muhammad al-Husaini al-Hisani ad-Dimasyqi asy-Syafi'i, Kifayah al-Akhyar, Surabaya: al-Hidayah, t.t.

Undang Undang Perpajakan No 36 Tahun 2008

Undang-Undang No. 23 Tahun 2011 tetang Pengelola Zakat, Bab 1 Pasal 1 Ayat 2.

Undang-undang Republik Indonesia Nomor 38 Tahun 1999 Tentang Pengelolaan Zakat

Undang-undang Republik Indonesia, Nomor 17 Tahun 2000 Tentang Pajak Penghasilan

Zaenudin, A.Rahman. (2000). Berbagai pandangan tentang zakat: Implikasinya pada pemerataan, Jakarta: paramadina. 